\title{
Pkm Pemberdayaan Guru Sekolah Dasar dalam Penguatan Pendidikan Karakter (PPK) Di Kecamatan Tulangan Sidoarjo
}

\author{
Fitria Wulandari ${ }^{1}$, Rugaya Meis Andhiarini ${ }^{2}$ \\ wulandarifitria17@gmail.com \\ Fakultas Keguruan dan Ilmu Pendidikan \\ Universitas Muhammadiyah Sidoarjo
}

\begin{abstract}
Character education is very important for elementary students. Character education in elementary schools will teach the habits of thinking and behavior that help students to live and work together in the family, community, and nation. Some of the problems that arise in the world of education include the lack of exemplary character of teachers to students, low understanding of teachers about character education, and lack of training for teachers to understand the importance of character education. It encourages proposers to incorporate ideas and ideas that solve the problem in training activities. So the proposer takes title of Teacher Empowerment elementary school in Strengthening Character Education in District Tulangan Sidoarjo. The ang approach method is used in devotion to this community with training activities. To know the success of the training activities, the proposal proponent will carry out the mentoring after the training activity has ended. The result of this dedication to the community can be concluded that the training is quite successful where the trainees are very enthusiastic in the training activities, it is also because each teacher has not received socialization from the government related to the government policy by providing Character Education reinforcement in School. From the results of the mentoring shows each teacher has developed an understanding and knowledge related to character education in schools. It is apparent from the results of anget teachers who have implemented character education in various activities at school.
\end{abstract}

\section{Keywords: Empowerment of Elementary Teachers, Reinforcement Character Education}

Abstrak: Pendidikan karakter sangat penting diterapkan pada siswa SD. Pendidikan karakter di SD akan mengajarkan kebiasaan berpikir dan berperilaku yang membantu siswa untuk hidup dan bekerja sama di lingkungan keluarga, masyarakat, dan bangsa. Beberapa permasalah yang muncul dalam dunia pendidikan antara lain meliputi kurang keteladanan karakter guru kepada siswa, rendahnya pemahaman guru tentang pendidikan karakter, serta kurangnya pelatihan bagi guru untuk memahami pentingnya pendidikan karakter. Hal tersebut mendorong pengusul proposal memadukan ide-ide dan gagasan-gagasan yang dalam menyelesaikan permasalah tersebut dalam kegiatan pelatihan. Sehingga pengusul proposal mengambil judul Pemberdayaan Guru SD dalam Penguatan Pendidikan Karakter di Kecamatan Tulangan Sidoarjo. Metode pendekatan ang digunakan dalam pengabdian kepada masarakat ini dengan kegiatan pelatihan. Untuk mengetahui keberhasilan kegiatan pelatihan tersebut pengusul proposal akan melalkukan 
pendampingan setelah kegiatan pelatihan berakhir. Hasil Pengabdian Kepada Masyarakat ini dapat ditarik kesimpulan bahwa pelatihan ini cukup berhasil dimana peserta pelatihan sangat antusias dalam kegiatan pelatihan, hal tersebut juga karena masing-masing guru belum pernah mendapatkan sosialisasi dari pemerintah terkait kebijakan pemerintan dengan memberikan Penguatan Pendidikan Karakter di Sekolah. Dari hasil pendampingan menunjukkan masing-masing guru telah mengembangkan pemahaman dan pengetahuannya terkait Pendidikan karakter di sekolah. Hal tersut tampak dari hasil anget guru yang telah menerapkan pendidikan karakter di berbagai kegiatan di sekolah

\section{Kata kunci:Pemberdayaan Guru SD, Penguatan Pendidikan Karakter $(P P K)$}

\section{ANALISIS SITUASI}

Karakter berasal dari Bahasa Latin yang artinya "dipahat". Secara harfiah, karakter merupakan kualitas mental atau moral, kekuatan moral, nama, atau reputasinya (Rutland dalam M. Furqon Hidayatullah (2009:1)). Karakter juga dapat diartikan sebagai sikap, tabiat, kepribadian, dan akhlak. Sedangkan menurut Khan (2010), pendidikan karakter adalah proses kegiatan yang mengarahkan pada peningkatan kualitas pendidikan dan pengembangan budi harmoni yang selalu mengajarkan, membimbing, dan membina setiap manusia untuk memiliki kompetensi intelektual, karakter, dan keterampilan manarik. Kompetensi karakter tersebut dapat dilakukan dengan menanamkan nilai-nilai karakter.

Nilai-nilai dalam pendidikan karakter dapat membantu berinteraksi dengan orang lain secara baik. Nilai tersebut mencakup berbagai bidang kehidupan, seperti hubungan dengan sesama (orang lain, keluarga), diri sendiri, hidup bernegara, lingkungan dan Tuhan (Muslih, M, (2011)). Dengan demikian guru senyongyanya dapat menerapkan nilai-nilai tersebut dalam pendidikan karakter di sekolah. Pendidikan Karakter merupakan strategi untuk mendidik anak di zaman modern (Doni Koesoema A, (2010)). Dalam pendidikan karakter peran guru sangat diutamakan untuk mengembangkan kepribadian siswa.

Guru merupakan suri tauladan pendidikan karakter di Sekolah. Guru adalah profesi. Sehingga untuk menjadi seorang guru harus memiliki kempetensi-kompetensi. Menurut Dja'man Satori, dkk (2010: 1.18) menyebutkan bahwa syarat guru yang professional memiliki beberapa kompetensi yaitu kompetensi professional, kompetensi personal, dan kompetensi sosial.Dari kompetensi tersebut kompetensi personal seorang guru akan memberikan karakter kepada siswa. Dengan kata lain, dalam kompetesni personal guru harus memiliki kepribadian untuk dapat digunakan sebagai teladan bagi siswa.

E. Mulyasa (2005) menyebutkan bahwa fungsi guru itu bersifat multifungsi. Guru tidak hanya sebagai pendidik tetapi juga sebagai pengajar, pembimbing, pelatih, penasihat, 


\section{Fitria Wulandari ${ }^{1}$, Rugaya Meis Andhiarini ${ }^{2}$}

pembaru, model, dan teladan, pribadi, peneliti, pendorong kreativitas, pembangkit pandangan, pekerja rutin, pemindah kemah, pembawa cerita, aktor, emansipator, evaluator, pengawet dan kulminator. Sikap dan perilaku seorang guru akan sangat membekas pada diri siswa. Sehingga ucapan, karakter, dan kepribadian seorang guru akan menjadi keteladanan bagi murid. Dengan demikian, pemberdayaan guru dalam penguatan pendidikan karakter itu sangat penting. Dalam dunia pendidikan pendidikan, Pendidikan karakter juga didukung dengan peraturan presiden Nomor 87 Tahun 2017 tentang penguatan pendidikan karakter.

Berdasarkan hasil observasi dan wawancara dengan beberapa guru Sekolah Dasar pada bulan Oktober 2017, dapat disimpulkan bahwa peguatan pendidikan karakter sangatlah penting untuk siswa, tetapi masih banyak kendala yang dihadapi dalam penerapannya. Salah satunya adalah kurangnya pemahaman guru tentang penguatan pendidikan karakter di sekolah. Hal tersebut mengakibatkan rendahnya usaha guru untuk memperkuat karakter siswa yang akan berakibat pula pada potensi karakter yang dimiliki oleh siswa. Selain itu kurangnya sarana dan prasarana yang mendukung penguatan pendidikan karakter di SD.

Berdasarkan permasalahan di atas, kami tertarik untuk melalukan pelatihan melalui program pengabdian kepada masyarakat dengan judul "PKM Pemberdayaan Guru Sekolah Dasar dalam Penguatan Pendidikan Karakter di Kecamatan Tulangan Sidoarjo”.

\section{METODE PELAKSANAAN}

Menurut (Sugiyono, 2012:226) menyatakan bahwa observasi adalah dasar dari semua ilmu pengetahuan. Metode observasi adalah metode yang menggunakan cara pengamatan terhadap objek yang menjadi pusat perhatian pada penelitian. Berdasarkan hasil observasi awal dengan sekolah mitra menunjukkan bahwa guru di sekolah mitra masih kurang pemahaman pendidikan karakter, sehingga dengan kesepakatan dari sekolah mitra untuk menyelesaikan permasalah tersebut maka pengusul proposal menggunakan metode pendekatan dengan kegiatan pelatihan dalam pengabdian kepada masyarakat ini. Untuk mengetahui keberhasilan kegiatan pelatihan tersebut pengusul proposal akan melalkukan pendampingan setelah kegiatan pelatihan berakhir. Dalam kegiatan pedampingan tersebut guru di sekolah mitra akan mengisi lembar angket/ kuesioner terkait pelaksanaan penguatan pendidikan karakter oleh guru yang bersangkutan. Data angket/kuesioner yang telah terkumpul selanjutnya akan diolah dan dideskripsikan oleh pengusul proposal. Data yang sudah dioleh dan dideskripsikan akan menjadi hasil kesimpulan dari kegiatan pengabdian masyarakat ini. 
Fitria Wulandari ${ }^{1}$, Rugaya Meis Andhiarini'

Pelatihan akan dilaksanakan dengan dua tahap yaitu teori dan praktek atau penerapannya yang berupa contoh-contoh kegiatan yang dapat memperkuat pendidikan karakter di sekolah dasar. Kerjasama sekolah mitra dan peran aktifnya dalam kegiatan pelatihan sangat diharapkan demi keberhasilan pelatihan ini. Dalam pelatihan ini akan didukung oleh beberapa narasumber yang akan menyampaikan materinya.

Pada kegiatan pertama peserta pelatihan akan menerima materi pentingnya pendidikan karakter dan arah kebijakan pemerintah tentang penguatan pendidikan karakter di sekolah. Kemudian pada tahap kedua peserta akan mendapatkan materi peran guru dalam pendidikan karakter serta praktek pelaksanaan pendidikan karakter di sekolah oleh guru SD.

\section{HASIL DAN PEMBAHASAN}

Langkah pertama yang harus dilakukan sebelum melakukan pengabdian yaitu melakukan observasi, tujuannya adalah mendapatkan informasi dan gambaran yang jelas mengenai sekolah mitra. Dari hasil observasi lanjutan yang dilakukan pada tanggal 4 Desember 2017, diperoleh sebuah deskripsi atau gambaran situasi bahwa mitra 1 dan 2 yang belum pernah mendapatkan sosialisasi tentang Penguatan Pendidikan Karakter.

Kegiatan Pengabdian kepada masyarakat ini dilaksanakan di Kecamatan Tulangan Kabupaten Sidoarjo dengan tema pemberdayaan guru SD dalam penguatan pendidikan karakter di sekolah. Tema tersebut tepat mengingat pada saat diskusi dengan sekolah mitra belum memahami tentang penguatan pendidikan karakter (PPK) yang dicanangkan oleh pemerintah. Pengabdian kepada masyarakat ini dilaksanakan pada hari Kamis tanggal 18 Januari 2018 dan hari Sabtu 27 Januari 2018, Hasil dari Abdimas adalah terlaksananya beberapa kegiatan untuk mengatasi masalah yang dihadapi sekolah mitra diantaranya :

\section{a. Wawasan dan Pengetahuan tentang Penguatan Pendidikan Karakter(PPK)}

Permasalahan kurangnya pemahaman tentang penguatan pendidikan karakter di sekolah mitra menyebabkan perlunya sosialisasi tentang penguatan pendidikan karakter. Kegiatan sosialisasi ini juga mendukung kebijakan pemerintah yang tertuang dalam peraturan presiden Nomor 87 tahun 2017. Dalam hal ini sosialisasi di lakukan dengan pemaparan materi dan diskusi tentang:
a. Pemaparan pentingnya pendidikan karakter untuk siswa.
b. Peran guru dalam penguatan pendidikan karakter
c. Metodologi dalam pendidikan karakter.
d. Tips efektif penguatan pendidikan karakter di sekolah. 
Fitria Wulandari $^{1}$, Rugaya Meis Andhiarini ${ }^{2}$

Pada kegiatan sosialisasi ini menghadirkan pembicara dalam bidang psikologi dan juga pendidikan yang dilaksanakan kurang lebih dua jam setengah ini, pemateri 1 (Rugaya Meis Andhiarini, M.Psi) dan kedua (Ibu Fitria Wulandari, M.Pd). Para pemateri memberikan materi dengan menggunakan LCD Proyektor dan tampilan power point. Jumlah peserta dalam kegiatan sosialisasi ini adalah sebanyak 25 peserta dari 2 sekolah mitra yaitu SD Muhammadiyah 8 Tulangan dan SD Muhammadiyah 2 Tulangan. Semua peserta dalam acara ini berpartisipasi secara aktif dengan kehadiran dan kepulangan yang tepat waktu. Pada kesempatan ini sekolah mitra terlihat mendengarkan sosialisasi yang disampaikan oleh pemateri.

Sosialisasi materi pertama disampaikan oleh ibu Rugaya Meis Andhiarini, M.Psi dengan materi pentingnya pendidikan karakter untuk siswa. Setelah kurang lebih 1 jam penyampaian materi selanjutnya moderator yang dalam kegiatan ini adalah mahasiswa PGSD semester 3 membuka sesi tanya jawab.

\section{b. Pelatihan Pemberdayaan Guru SD dalam Penguatan Pendidikan Karakter}

Setelah dilaksanakan sosialisasi tentang karakter, pendidikan karakter, dan pentingnya pendidikan karakter, pemateri 2 (Ibu Fitria Wulandari, M.Pd.) memberikan pelatihan pemberdayaan guru SD untuk penguatan pendidikan karakter. Dalam hal ini terdapat tiga kegiatan utama dala pelatihan yaitu :

\section{Pemaparan materi tentang metodologi dalam pendidikan karakter}

Pada sesi ini pemateri 2 menjelaskan beberapa metodologi dalam pendidikan karakter. Pendekatan yang dapat diterapkan dalam pendidikan karakterantara lain berbagai kegiatan yang dilakukan secara intra kurikuler maupun ekstra kurikuler. Kegiatan pendidikan karakter yang didasarkan pada intra kurikuler terintegrasi ke dalam mata pelajaran. Sedangkan kegiatan pendidikan karakter dalam ekstra kurikuler dilakukan di luar jam pelajaran. Sehingga perlu metodologi, penerapan metodologi yang efektif, aplikatif, dan produktif dalam pendidikan karakter dapat mencapai tujuan dengan baik. Ada beberapa metodologi dalam pendidikan karakter, antara lain keteladanan, penanaman kedisiplinan, pembiasaan, menciptakan suasana yang konduksif, integrasi dan internalisasi, serta pembinaan.

\section{Pemaparan materi tentang peran guru dalam pendidikan karakter}

Sesi selanjutnya yaitu penjelasan tentang peran guru dalam pendidikan karakter. Guru bertanggung jawab besar dalam menghasilkan generasi-generasi muda yang berkarakter, berbudaya, dan bermoral. Keteladanan guru memiliki peranan yang sangat besar dalam pembentukan karakter siswa. 


\section{Pemaparan materi tentang tips efektif pendidikan karakter di sekolah}

Kegiatan terakhir adalah pemaparan tentang tips efektif pendidikan karakter disekolah. Pemateri memberiakan cara efektif penerapan pendidikan karakter yang dapat diterapkan di sekolah mitra. Dari hasil tana jawab sekolah mitra telah menjalankan beberapa tips tetapi ada beberapa tips yang masih belum diterapkan disekolah mitra. Peserta pelatihan ada beberapa yang bertanya.. Setelah kira-kira satu jam 30 menit, setelah itu adalah kegiatan penutupan yang disampaikan oleh ketua pelatihan sekaligus pemateri 2 dan berdoa.

\section{c. Monitoring Pemberdayaan Guru SD dalam Penguatan Pendidikan Karakter}

Kegiatan selanjutnya dilaksanakan pada tanggal 27 Januari 2018. Ketua dan anggota abdimas melakukan monitoring terhadap pemberdayaan guru SD dalam penguatan pendidikan karakter dengan memberikan angket kepada peserta pelatihan dari sekolah mitra. Monitoring tersebut berupa tindak lanjut dari hasil pelatihan Penguatan Pendidikan Karakter di SD. Tindak lanjut tersebut berisi kegiatan pengembangan kapasitas guru dalam Penguatan Pendidikan Karakter dalam bentuk deskripsi, serta nilai utama Penguatan Pendidikan Karakter di Sekolah, uraian alasannya, dan uraian kaitan dengan nilai-nilai karakter yang lainnya.

Berdasarkan angket yang terkumpul dari sekolah mitra diperoleh hasil bentuk kegiatan dalam rangka pengembangan Penguatan Pendidikan Karakter antara lain dengan kegiatan berdoa, shalat berjamaah, merapikan sepatu, tadarus dan tahfid, out bond, seminar parenting, out door learning, memberbanak literasi tentang tokoh, berbaris dan menium tangan guru, bisnis day dengan berinfaq, dan jum'at bersih.

Sedangkan nilai utama di sekolah mitra yang telah ditanamkan antara lain membentuk karakter religius sesuai dengan syariat Nabi Muhammad dan Al-Quran serta sosial . Nilai tersebut ditanamkan dengan pembiasaan (habituality) setiap harinya. Adapun beberapa alasann sebagai berikut :

a. Supaya siswa mempunyai akhlakul karimah, cerdas, berilmu, dan santun.

b. Supaya siswa terbiasa dengan perilaku disiplin, mandiri

c. Semua nilai karakter yang baik dapat tertanam dijiwa siswa dengan pembiasaan

d. Supaya siswa menjadi pribadi yang lebih baik

Selanjutnya dari alasan tersebut guru di sekolah mitra memberikan jalinan nilai utama dengan nilai karakter yang lain, antara lain: Disiplin, Tanggung jawab, Percaya diri, 


\section{Fitria Wulandari ${ }^{1}$, Rugaya Meis Andhiarini ${ }^{2}$}

Kepemimpinan yang kuat, Kreatif, Menghargai orang lain, Toleransi, Gemar membaca, Cinta lingkungan, Peduli, Jujur, Mandiri, dan lain-lain.

\section{SIMPULAN}

Berdasarkan hasil Pengabdian Kepada Masyarakat di kecamatan Tulangan dengan judul pemberdayaan guru SD dalam Penguatan Pendidikan Karakter (PPK) dapat ditarik kesimpulan bahwa pelatihan ini cukup berhasil dimana peserta pelatihan sangat antusias dalam kegiatan pelatihan, hal tersebut juga karena masing-masing guru belum pernah mendapatkan sosialisasi dari pemerintah terkait kebijakan pemerintan dengan memberikan Penguatan Pendidikan Karakter di Sekolah. Dari hasil pendampingan menunjukkan masingmasing guru telah mengembangkan pemahaman dan pengetahuannya terkait Pendidikan karakter di sekolah. Hal tersut tampak dari hasil anget guru yang telah menerapkan pendidikan karakter di berbagai kegiatan di sekolah.

Saran yang dapat diberikan yaitu sebelum meminta siswa untuk memiliki karakter, sebaiknya guru telah memiliki karakter yang baik. Karena guru adalah suri tauladan dan panutan bagi siswa di sekolah. Serta sekolah juga harus dapat memfasilitasi dan meberikan kebijakan terkait pendidikan karakter anak di sekolah.

\section{DAFTAR PUSTAKA}

Albertus. Doni Koesoema. 2010. Pendidikan Karakter; Strategi Mendidik Anak di Zaman Global. Jakarta: Grasindo.

Asmani, Ma'mur, J.2012. Pendidikan Karakter di Sekolah. Jogjakarta : DIVA Press.

Hidayatullah, M. Furqon. 2010. Pendidikan Karakter; Membangun Peradapan Bangsa.

Surakarta: Yuma Pustaka

Kemdikbud, 2017. Konsep dan Pedoman Penguatan Pendidikan Karakter Tingkat Sekolah Dasar dan Sekolah Menengah Pertama.

Masnur Muslih. 2011. Pendidikan Karakter Menjawab Tantangan Krisis Multidimensional. Jakarta: Bumi Aksara.

Mulyasa, E. 2005. Menjadi Guru Profesional, Menciptakan Pembelajaran Kreatif dan Menyenangkan. Bandung: Rosda.

Mustakim, Bagus. 2011. Pendidikan Karakter Membangun Delapan Karakter Emas Menuju Indonesia Bermartabat. Yogyakarta: Samudra Baru.

Peraturan Pesiden Nomor 87 Tahun 2017 tentang penguatan pendidikan karakter Sugiyono. 2012. Metode Penelitian Kuantitatif Kualitatif Dan R\&D. Bandung: Alfabeta. 
Fitria Wulandari ${ }^{1}$, Rugaya Meis Andhiarini ${ }^{2}$

Undang-undang Republik Indonesia Nomor 20 tahun 2003. Tentang Sistem pendidikan nasional.

Yahya, Khan. 2010. Pendidikan Karakter Berbasis Potensi Diri. Jakarta: PT.Grasindo. 
Fitria Wulandari ${ }^{1}$, Rugaya Meis Andhiarini ${ }^{2}$ 
Fitria Wulandari ${ }^{1}$, Rugaya Meis Andhiarini ${ }^{2}$ 
Fitria Wulandari ${ }^{1}$, Rugaya Meis Andhiarini ${ }^{2}$ 